\title{
ATUAÇÃO DO CADE E DO PODER JUDICIÁRIO NA QUESTÃO DA RESPONSABILIDADE CIVIL CONFIGURADA EM RAZÃO DE ILÍCITOS CONCORRENCIAIS NO ÂMBITO DO DIREITO DO CONSUMIDOR: UMA ANÁLISE DAS DECISÕES NÃO COINCIDENTES
}

\author{
CADE'S PERFORMANCE AND THE JUDICIARY ON THE ISSUE OF CIVIL \\ RESPONSABILITY SET DUE TO ILLEGAL COMPETITVE CONDUCTS IN THE \\ SCOPE OF CONSUMER LAW: AN ANALYSIS OF NON-COINCIDENT DECISIONS
}

${ }^{1}$ Larissa Thomaz Coelho

\begin{abstract}
RESUMO
O presente artigo traz em seu bojo a análise da relação existente entre o direito concorrencial e o direito do consumidor, especialmente no que diz respeito à questão da reclamação, pelos titulares deste último, de reparação civil tendo como base danos causados por ilícitos concorrenciais. Visando compreender como se dá essa relação no Direito Brasileiro, serão estudadas as decisões desse cunho proferidas tanto pelo poder judiciário, quanto pelo Tribunal Administrativo do Conselho Administrativo de Defesa Econômica (CADE), tornando-se importante estabelecer as implicações de possíveis decisões divergentes acerca da configuração de ilícito concorrencial no âmbito de cada uma das esferas.
\end{abstract}

Palavras-chave: Concorrência, Consumidor, Responsabilidade civil, Ação civil pública, Ilícito concorrencial, Indenização

\begin{abstract}
This article brings the analysis of the relationship between competition law and consumer rights, with special regard to the issue of the claims made by the holders of these rights of civil damages based on the harms caused by unlawful competitive. Seeking to understand how is this relationship in the Brazilian law, decisions of this nature handed down by both the judiciary and the Administrative Council for Economic Defense Court (CADE) will be studied, making it important to establish the implications of possible divergent decisions concerning the competitive illicit configuration within each of the spheres.
\end{abstract}

Keywords: Competition, Consumer, Civil responsability, Public civil action, Illicit competition, Indemnity

\footnotetext{
${ }^{1}$ Mestranda em Direito pela Universidade Federal do Estado do Rio de Janeiro - UNIRIO, Rio de Janeiro (Brasil). E-mail: larissathomazc@yahoo.com.br
} 


\section{INTRODUÇÃO}

É bastante comum - e certamente natural - que, ao pensarmos no direito da concorrência, foquemos de forma direta, automática e exclusiva nas matérias de mercado. Ocorre que as questões concorrenciais vão além e impactam outros ramos jurídicos. Um deles é o referente ao consumo, objeto do presente estudo, e que se vê especialmente atingido pela seara concorrencial quando da configuração de infrações econômicas.

O presente artigo se destinará, por meio de uma análise legal, doutrinária e jurisprudencial, a investigar essa relação entre as infrações concorrenciais e o consumidor no que tange a possibilidade de reclamação deste por indenização na esfera cível. Serão estudados os aspectos da judicialização do direito da concorrência, especialmente por meio do ajuizamento das chamadas Ações Civis Públicas na seara consumerista, bem como, e por meio de um paralelismo, os julgamentos dessas referidas questões em âmbito judiciário e administrativo (Conselho Administrativo de Defesa Econômica - CADE), suscitando-se as questões decorrentes de uma possível discrepância entre esses julgamentos, qual seja, a de a esfera cível entender pela configuração de ato ilícito num determinado caso concreto, enquanto a esfera administrativa entender o oposto.

Nesse ínterim, revela-se importante iniciar o presente estudo pela compreensão da relação estreita que existe entre a concorrência no mercado e as relações consumeristas.

\section{A relação entre o direito concorrencial e o direito do consumidor}

Embora a instituição jurídica de uma real ordem econômica tenha se tornado real no direito brasileiro com o advento da Constituição de $1934^{1}$, foi apenas na Carta Magna de $1988^{2}$ que o Estado passou a assumir - formalmente e definitivamente - um papel em relação à economia até então não vislumbrado pelas Constituições anteriores: de intervencionista e nacionalista, torna-se agente regulador e normativo.

De fato, o que se percebe é que a entidade Estatal deixa cada vez mais de lado a sua postura de agente econômico e abraça com mais vigor a sua função de garantidor da estabilidade e da segurança de mercado, lançando mão, para isso, de políticas públicas de

\footnotetext{
${ }^{1}$ O referido diploma trazia em seu conteúdo o Título IV, denominado "Da Ordem Econômica e Social" e contava com 28 artigos (art. 115 ao art. 143). BRASIL. Constituição de 1934. Diário Oficial: 16 de julho de 1934.

${ }^{2}$ Conforme se observa no seu Título VII, intitulado "Da Ordem Econômica e Financeira" e capítulos. BRASIL. Constituição da República Federativa do Brasil. Diário Oficial da União: 5 de outubro de 1988.
} 
cunho econômico. Essa nova faceta do Estado é, em verdade, uma imposição dessa nova ordem econômica ${ }^{3}$ constitucionalmente positivada, que em seu bojo traz preceitos e princípios que devem ser necessariamente observados. É justamente nessa última categoria, a de princípios, que se encontram a livre concorrência e a defesa do consumidor, aos quais, pela primeira vez na história brasileira, são elevados a referido status. Assim prevê o artigo 170, da Constituição Federal (BRASIL, 1988):

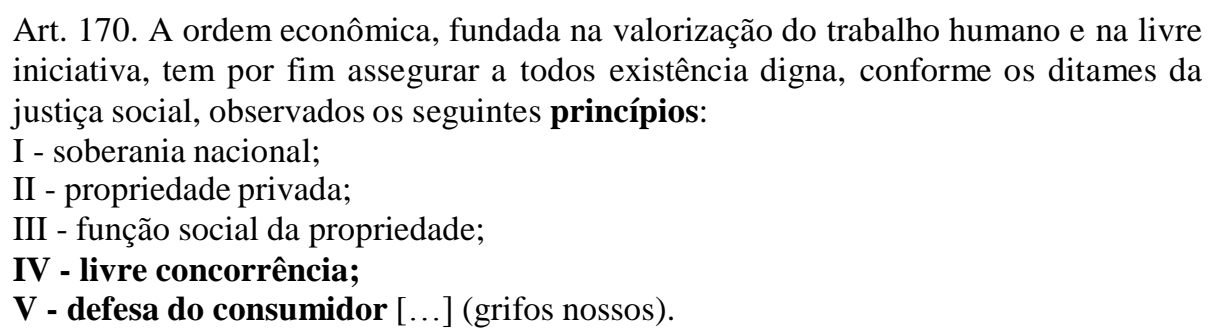

Indubitavelmente, o legislador constituinte teve a sensibilidade não só de perceber, mas também de reconhecer, no principal instrumento legislativo do nosso ordenamento jurídico, a relação existente entre a seara consumerista e a econômica, mais especificamente - e de maior relevância para o presente estudo - no que tange ao seu aspecto concorrencial. Tal relação se mostrou na prática tão intensa, que foi cogitada, inclusive,

\begin{abstract}
“[...] a criação de uma agência única, a Agência de Defesa do Consumidor e da Concorrência (ANC), que visava a reunir em uma mesma instituição o Sistema Brasileiro de Defesa da Concorrência (SBDC) e o Sistema Nacional de Defesa do Consumidor (SNDC). Superada a fase de estudos e pesquisas acerca de um modelo institucional ideal à defesa da concorrência, concluiu-se pelo fortalecimento do Conselho Administrativo de Defesa Econômica (CADE), que, com a edição da Lei 12.529/11, absorveu as competências do Departamento de Proteção e Defesa Econômica (DPDE) da Secretaria de Direito Econômico (SDE) e passou a contemplar uma Superintendência-Geral com uma Procuradoria Geral, um Departamento de Estudos Econômicos e um Tribunal Administrativo. Ao Direito do Consumidor, por sua vez, coube a criação em 2012 da Secretaria Nacional do Consumidor (SENACON)." (CRAVO, 2013, P. 55)
\end{abstract}

É bem verdade que os objetivos de cada uma das duas matérias aqui abordadas se mostram tão específicos e diversos que, em nosso ordenamento, eles são tutelados por ramos

\footnotetext{
${ }^{3}$ Ou, como denomina Claudia Lima Marques, "Ordem Pública Econômica", tendo em vista o fenômeno da constitucionalização do direito privado. Nas palavras da autora: "O direito privado sofre hoje uma influência direta da Constituição, da nova ordem pública por ela imposta, e muitas relações particulares, antes deixadas ao arbítrio da vontade das partes, obtêm uma relevância jurídica nova e um conseqüente controle estatal, que já foi chamado de 'publicização do direito privado' e, hoje, de direito civil constitucional, a denotar o domínio das linhas de ordem pública constitucional sobre as relações privadas.” (MARQUES, 2006, p.61).
} 
jurídicos e legislativos distintos, o que, porém, não significa dizer que entre eles não haja um elo harmônico de profunda intensidade.

De fato, o Direito Concorrencial se destina precípua e diretamente a tutelar o mercado em si e em toda sua estrutura, ocupando-se de questões como a competição, a livre iniciativa, a eficiência, a repressão ao abuso de poder econômico e também, conforme o próprio artigo $1^{\mathrm{o}}$ da Lei Antitruste brasileira ${ }^{4}$ (Lei 12.529/2011), a defesa do consumidor. O próprio direito da concorrência - ainda que inspirado por uma determinação constitucional - reconhece a íntima relação do consumidor com o mercado, uma vez que aquele é parte deste, não havendo, no sistema capitalista, mercado sem consumo.

E foi diante da importância do consumidor, bem como da sua reconhecida posição de hipossuficiência ante os outros atores econômicos, que a Constituição Federal o instituiu como sujeito de direitos não somente individuais, mas igualmente de direitos comuns a um mesmo grupo (sob a proteção, no mínimo, de direitos individuais homogêneos), estando reservado às relações de consumo um ramo do Direito próprio: o direito do consumidor, regulado atualmente pela Lei ordinária 8.078, publicada no dia 11 de setembro de 1990, que vem a ser o Código de Defesa do Consumidor pátrio (CODECON) ${ }^{5}$.

Há, entretanto, que se suscitar a controvérsia existente na comunidade acadêmica acerca de poder considerar o consumidor e o seu bem-estar como fim último do direito concorrencial. Em outras palavras, há um debate entre os autores para saber se o direito concorrencial e o direito do consumidor, em seus reconhecidos papéis e lógicas distintas, apresentam, no fim das contas, o mesmo destinatário final, qual seja, o consumidor.

Uma primeira corrente defende que a finalidade primordial do direito da concorrência nada mais é do que o próprio mercado; uma segunda prega que, na verdade, o objetivo principal do direito concorrencial é a tutela dos interesses da coletividade; e, por fim, uma terceira - a ser adotada no presente artigo -, defendida por autores como Fábio Konder Comparato (1978), Leonardo Vizeu Figueiredo (2010) e Heloísa Carpena (2005), sustenta o

\footnotetext{
${ }^{4}$ É o que se depreende da leitura do referido artigo, in verbis: "Art. 1- ${ }^{\circ}$ Esta Lei estrutura o Sistema Brasileiro de Defesa da Concorrência - SBDC e dispõe sobre a prevenção e a repressão às infrações contra a ordem econômica, orientada pelos ditames constitucionais de liberdade de iniciativa, livre concorrência, função social da propriedade, defesa dos consumidores e repressão ao abuso do poder econômico." (BRASIL. Lei n ${ }^{\circ}$ 12.529, 2011).

${ }^{5}$ O Código de Defesa do Consumidor (CODECON) veio de modo a cumprir com o determinado pelo art. $5^{\circ}$, XXXII, da Constituição da República Federativa do Brasil: "Art. $5^{\circ}$ Todos são iguais perante a lei, sem distinção de qualquer natureza, garantindo-se aos brasileiros e aos estrangeiros residentes no País a inviolabilidade do direito à vida, à liberdade, à igualdade, à segurança e à propriedade, nos termos seguintes: [...] XXXII - o Estado promoverá, na forma da lei, a defesa do consumidor.” (BRASIL. Constituição da República Federativa do Brasil, 1988).
} 
entendimento de que o consumidor e seus interesses constituem o norte máximo das Políticas Concorrenciais. Para essa corrente, o consumidor apresenta uma verdadeira posição de destaque, sendo considerado um agente econômico essencial, capaz de fomentar a concorrência e, por essas razões, é o real destinatário do direito concorrencial. Nas palavras de Figueiredo (2010, p. 218):

\begin{abstract}
A fixação de políticas públicas para a defesa da concorrência e da liberdade de mercado denota que o exercício das liberdades individuais deve ser disciplinado de forma racional pelo Estado, de modo a garantir que o consumidor, parte hipossuficiente no ciclo econômico (produção, circulação e consumo), e o próprio Poder Público não fiquem a mercê de medidas arbitrárias impostas pelos agentes detentores de poder econômico.
\end{abstract}

De qualquer sorte, seja qual for a corrente defendida, o fato é que a relação entre concorrência e consumidor é real. Tanto é assim que a nossa Constituição, acertadamente, previu esse elo entre ambas as matérias. Ainda que não se defenda o posicionamento do consumidor como verdadeiro destinatário do direito concorrencial, o fato é que as relações de consumo fazem sim parte da concorrência econômica.

Como visto, para os fins do presente estudo, será adotado o posicionamento da terceira corrente, qual seja, a que entende o consumidor como fim último do Direito Concorrencial. Vale ressaltar, contudo, que a essa afirmação não corresponde dizer que a tutela do consumidor pelo direito da concorrência será direta e imediata; muito pelo contrário. Como bem coloca Cravo (2013, p. 58):

\footnotetext{
Perceba-se, portanto, que em decorrência de sua natureza e finalidade diversa, cada ramo irá proteger o consumidor de maneira distinta. No tocante ao Direito da Concorrência, imperioso esclarecer que o fato de o consumidor ser o destinatário econômico final das normas concorrenciais, não o transforma em destinatário jurídico direto das mesmas, como bem coloca Calixto Salomão. Muito pelo contrário, em alguns casos, se o consumidor fosse o destinatário direto da norma, a tutela estaria fadada à ineficácia.

[...] Como regra, então, a tutela do consumidor, através do Direito da Concorrência, será realizada de forma indireta, através da proteção de outros interesses, como o interesse da instituição concorrência ou os interesses dos concorrentes.
}

Nesse ínterim, ressaltem-se também os ensinamentos de Gilberto de Abreu Sodré Carvalho (2004, p. 647):

Nesse quadro, a defesa das estruturas da concorrência é instrumento para o atendimento do interesse público e dos consumidores no longo prazo, prestigiada a dignidade humana pela possibilidade do seu direito amplo de iniciativa, de escolha, de definição e de especificação das suas próprias necessidades econômicas. [...] Os interesses do consumidor são satisfeitos por consequência da proteção da 
concorrência. Só assim a dignidade do ser humano, que está por trás e acima do consumidor, será cabalmente atendida. (grifos nossos)

Entretanto, autores como Calixto Salomão Filho (2003, p. 85) ensinam que, a título de exceção, no que tange aos ilícitos decorrentes de abuso de posição dominante, a titularidade dos consumidores no âmbito do direito concorrencial será direta. Tendo seu combate sido expressamente determinado pelo artigo $1^{\circ}$ da já citada Lei $12.529 / 11$, as condutas que se configuram como economicamente abusivas encontram-se elencadas num rol exemplificativo tanto no $\mathrm{CODECON}^{6}$, como na Lei Antitruste ${ }^{7}$. Sendo assim, em verdade, podese afirmar, com base no artigo $7^{\circ}$, caput, do $\operatorname{CODECON}^{8}$, que serão consideradas práticas abusivas qualquer comportamento que afete diretamente o consumidor, ainda que não previstos nesse referido Código.

Essa constatação se mostra como essencial e em consonância com a legislação pátria no que se refere à reclamação de responsabilidade civil pelo consumidor no âmbito do Direito Concorrencial. Analisemos, a seguir, a questão com mais profundidade.

\section{Reclamação de reparação civil pelo consumidor no âmbito do direito concorrencial}

Em linhas gerais, conforme o Código Civil Brasileiro em seus artigos $186^{9}$ e $927^{10}$, haverá obrigação de indenizar (ou seja, caberá reparação civil) sempre que for constatada, no caso concreto, a presença de ato ilícito, de lesão ou dano e de nexo causal entre os dois primeiros. E à determinação legal acerca da configuração da responsabilidade civil no direito civil pátrio não fogem os casos relativos à seara concorrencial.

\footnotetext{
${ }^{6}$ Esse rol encontra-se disposto na Seção IV “Das Práticas Abusivas”, artigos 39 ao 41. (BRASIL. Lei n 8.078, 1990).

${ }^{7}$ Nessa Lei, essas condutas abusivas são denominadas de "infração à ordem econômica". (BRASIL. Constituição da República Federativa do Brasil, 1988).

${ }^{8} \mathrm{O}$ referido artigo prevê que "os direitos previstos neste código" não excluem outros decorrentes de tratados ou convenções internacionais de que o Brasil seja signatário, da legislação interna ordinária, de regulamentos expedidos pelas autoridades administrativas competentes, bem como dos que derivem dos princípios gerais do direito, analogia, costumes e equidade.” (BRASIL. Lei nº 8.078, 1990).

9 Art. 186 Aquele que, por ação ou omissão voluntária, negligência ou imprudência, violar direito e causar dano a outrem, ainda que exclusivamente moral, comete ato ilícito. (BRASIL. Código Civil, 2012).

10 Art. 927 Aquele que, por ato ilícito (arts. 186 e 187), causar dano a outrem, fica obrigado a repará-lo. Parágrafo único. Haverá obrigação de reparar o dano, independentemente de culpa, nos casos especificados em lei, ou quando a atividade normalmente desenvolvida pelo autor do dano implicar, por sua natureza, risco para os direitos de outrem. (BRASIL. Código Civil, 2012).
} 
Ora, não podia ser diferente. Os atos ilícitos cometidos no âmbito do direito da concorrência - dentre os quais vários se encontram discriminados num rol exemplificativo de infrações, como já visto - são potencialmente causadores de dano, sejam eles diretos ou indiretos, capazes de atingir a esfera individual ou coletiva (direitos individuais homogêneos ${ }^{11}$ ). Assim preleciona o artigo 47 da Lei 12.529/11 (BRASIL, 2011):

Art. 47. Os prejudicados, por si ou pelos legitimados referidos no art. 82 da Lei $\mathbf{n}^{0}$ 8.078, de 11 de setembro de 1990, poderão ingressar em juízo para, em defesa de seus interesses individuais ou individuais homogêneos, obter a cessação de práticas que constituam infração da ordem econômica, bem como o recebimento de indenização por perdas e danos sofridos, independentemente do inquérito ou processo administrativo, que não será suspenso em virtude do ajuizamento de ação. (grifos nossos).

Tendo em vista o exposto até o presente momento, não restam dúvidas de que é, sim, o consumidor, um potencial prejudicado pelos atos ilícitos ocorridos no seio do direito da concorrência. E mais: não só o consumidor individualmente considerado pode sofrer esses danos, mas também quando considerado em seus interesses de grupo, de classe consumidora.

Tanto é assim que a própria Lei Antitruste, base do direito concorrencial, no artigo citado supra, faz referência direta ao Código de Defesa do Consumidor, especificamente ao seu artigo $82^{12}$, para determinar o rol de legitimados a reclamar indenização por danos sofridos.

Fato é que, no Brasil, semelhante ao que ocorre em países da Europa e diferentemente dos Estados Unidos - onde a prática citada a seguir já se encontra bastante consolidada -, a propositura de ações de indenização devido às condutas ilícitas concorrenciais ainda é bastante incipiente. De acordo com Gaban e Santos (2011), no Brasil:

\begin{abstract}
Os consumidores, de modo geral, não estão habituados a processar os agentes econômicos em razão de práticas ilícitas, quanto mais face à ilícitos concorrenciais. Não se sabe ao certo a razão: se em razão da morosidade da Justiça e dos custos de arcar com um processo, os consumidores não se valem dessa ferramenta para recuperar os danos, ou porque não se valem dessa ferramenta e, portanto, não há pressão suficiente sobre o sistema judiciário, não se tem a cultura de processar-se os causadores de danos por prática concorrencial. Seja como for, a falta de cultura de persecução civil dos danos acaba por gerar um efeito negativo e
\end{abstract}

\footnotetext{
${ }^{11}$ Conforme determina o art. 81, da Lei 8.078/90 (Código de Defesa do Consumidor), os direitos ou interesses individuais homogêneos são aqueles que apresentam origem comum. (DIMOULINS; MARTINS, 2008, p. 71)

${ }^{12}$ Art. 82. Para os fins do art. 81, parágrafo único, são legitimados concorrentemente: I - o Ministério Público; II - a União, os Estados, os Municípios e o Distrito Federal; III - as entidades e órgãos da Administração Pública, direta ou indireta, ainda que sem personalidade jurídica; especificamente destinados à defesa dos interesses e direitos protegidos por este código; IV - as associações legalmente constituídas há pelo menos um ano e que incluam entre seus fins institucionais a defesa dos interesses e direitos protegidos por este código, dispensada a autorização assemblear. (BRASIL. Lei nº 8.078, 1990.)
} 
não desejado na própria prática judiciária: os juízes, no Brasil, não têm cultura de aplicar indenizações minimamente suficientes a reparar os danos causados e, ao mesmo tempo, dissuadir futuras práticas ilícitas. À pecha de proteger-se da temida criação da "indústria da indenização", não raras vezes, quando interpelados, os juízes alegam que atribuir indenizações exemplares daria ensejo à criação da "indústria da indenização", tal como ocorre nos EUA. A pergunta que fica é a seguinte: ainda que houvesse tal indústria, não teria esta o condão de dissuadir a prática de ilícitos das mais variadas classes, sobretudo anticoncorrenciais e, assim, não estaria o consumidor brasileiro mais protegido como de fato está o consumidor norte-americano?

E continuam:

Importante observar que, no Brasil, dificuldades semelhantes à Europa são encontradas para ações de indenização, i.e., obstáculos legais e processuais para indenizações em matéria antitruste, em virtude de apresentarem características peculiares como a realização de complexas análises econômicas, dificuldade na obtenção de provas, ponderação entre o risco e eventual indenização etc. Adiciona-se à questão, além da morosidade da Justiça, o despreparo encontrado no âmbito Judiciário para julgamento de ações dessa natureza, que por consequência, dificulta o proferimento de sentenças compatíveis com a realidade da matéria. Em outras palavras, embora juridicamente possível a ação de reparação no Brasil, a falta de familiaridade com o antitruste aliada à ausência de uma cultura de reparação são obstáculos reais no contexto do Poder Judiciário Brasileiro.

De toda forma, ainda que pequena e pouco difundida, a busca dos consumidores lesados por reparação civil em razão de ilícitos concorrenciais vem, pouco a pouco, crescendo $^{13}$, principalmente sob a forma de demandas coletivas, restando ainda muito pouco - ou quase nada - o pleito individual. É, em especial, por meio do instrumento da Ação Civil Pública, ajuizada pelo Ministério Público, que essa referida busca vem ganhando contornos

mais concretos e densos no Direito pátrio. Analisemos a questão com mais cautela a seguir.

\footnotetext{
13 Segundo o advogado Arthur Villamil Martins (2015), esse aumento das ações de indenização por danos causados por ilícitos do direito da concorrência se deu, principalmente, no que diz respeito aos cartéis e devido a dois grandes acontecimentos: "O primeiro fato refere-se aos escândalos envolvendo cartéis em concorrências públicas, especialmente nas licitações promovidas pela Companhia Paulista de Trens Metropolitanos (cartel do Metrô de São Paulo) e nas licitações da Petrobrás (Operação Lava Jato), dando conta de possíveis prejuízos bilionários àquelas estatais, que deverão ser apurados por meio de ação própria. $\mathrm{O}$ segundo fato refere-se a uma importante mudança na forma de julgamento de processos de cartel pelo Cade - Conselho Administrativo de Defesa Econômica. Em julgados recentes (cartel das próteses medicinais, cartel dos gases) o Cade passou a calcular o sobrepreço imposto pelos participantes do cartel aos adquirentes de seus produtos ou serviços, que tem girado em média de $15 \%$ a $50 \%$ acima do preço regular. Esse sobrepreço é calculado a partir da diferença entre o preço cobrado pelos membros de um cartel e o preço que seria normalmente cobrado em regime de livre concorrência, caso o cartel não existisse. O valor do sobrepreço tem sido estimado a partir de cálculos econométricos e de análises contrafactuais que vêm sendo realizadas pelo Departamento de Estudos Econômicos do Cade, com aplicação do método "antes-e-depois" e do método de Cournot, dentre outros.” .
} 
Atuação do Cade e do Poder Judiciário na Questão da Responsabilidade Civil Configurada em Razão de Ilícitos Concorrenciais no Âmbito do Direito do Consumidor: Uma Análise das Decisões não Coincidentes

\section{Judicialização do direito concorrencial: a Ação Civil Pública como principal instrumento de tutela do consumidor}

A partir de uma leitura conjunta da Lei Antitruste, do Código de Defesa do Consumidor e da Lei 7.347 de 1985 (Lei da Ação Civil Pública) - especialmente o artigo 1º, inciso V, desta última ${ }^{14}$ - pode-se extrair a existência de dois tipos de litígio referentes às infrações à ordem econômica: o private antitrust enforcement e o public antitrust enforcement.

O private antitrust enforcement, cuja base é do direito norte-americano, é aquele que garante aos consumidores e demais prejudicados (até mesmo os próprios concorrentes) serem ressarcidos, uma vez que a via administrativa não é o fórum competente para tal demanda. Nesse tipo de litígio é que poderiam ser encontradas as demandas individuais por indenização de danos causados por ilícitos concorrenciais no que tange ao consumo.

Entretanto, como já afirmado acima, esse tipo de ação praticamente inexiste em nossos Tribunais. Além do mais, há pouquíssimos estudos dedicados e ele em nossa literatura ${ }^{15}$, sendo igualmente poucos os casos concretos desse tipo de litígio conhecidos na jurisprudência brasileira.

Curioso observar, nesse contexto, que o principal órgão administrativo do Sistema Brasileiro de Defesa da Concorrência (SBDC) ${ }^{16}$, qual seja, o Conselho Administrativo de Defesa Econômica $(\mathrm{CADE})^{17}$, fez questão de vigorosamente estimular a prática desse tipo de ação privada quando do famoso e emblemático julgamento do chamado "Cartel dos Gases" (Processo Administrativo $\mathrm{n}^{\mathrm{o}}$ 08012009888/2003-70, julgado em 01 de setembro de 2010.).

\footnotetext{
${ }^{14}$ Art. $1^{\circ}$ - Regem-se pelas disposições desta Lei, sem prejuízo da ação popular, as ações de responsabilidade por danos morais e patrimoniais causados: [...] V - por infração da ordem econômica. Redação dada pela Lei 12.529/11. (BRASIL. Lei 7.347,1985).

${ }^{15}$ É o que afirma Gisela Mation (2008) em pesquisa realizada na sua monografia, vencedora do III Prêmio Seae de Monografias em Defesa da Concorrência e Regulação Econômica de 2008.

${ }^{16}$ O Sistema Brasileiro de Defesa da Concorrência vem determinado no artigo $3^{\circ}$ da Lei $12.529 / 11$. In verbis: “Art. 3- O SBDC é formado pelo Conselho Administrativo de Defesa Econômica - CADE e pela Secretaria de Acompanhamento Econômico do Ministério da Fazenda, com as atribuições previstas nesta Lei." (BRASIL. Lei n 12.529 de 30 de novembro de 2011. Diário Oficial da União: 01 de dezembro de 2011.)

17 A estrutura e as atribuições do CADE estão dispostas na Lei $12.529 / 11$ do artigo $5^{\circ}$ ao 18 . Ainda, de acordo com definição da própria autarquia federal, "o Cade tem as atribuições de analisar e aprovar ou não os atos de concentração econômica, de investigar condutas prejudiciais à livre concorrência e, se for o caso, aplicar punições aos infratores e de disseminar a cultura da livre concorrência." (CADE. Perguntas Gerais sobre Defesa da Concorrência, 2015).
} 
Na decisão desse Processo Administrativo - o qual configura a maior multa já determinada pelo órgão ${ }^{18}$-, foi defendido o seguinte posicionamento:

\begin{abstract}
A multa imposta pelo Conselho não repara os danos patrimoniais e morais causados a pessoas específicas. A indenização por tais danos deve ser engendrada pelas vias judiciais cabíveis. A via de maior destaque é a ação civil pública (...). Merece destaque, ainda, a ação privada, ajuizada pela vítima do cartel em busca de reparação pelos danos causados. A utilidade de ações privadas para a promoção da concorrência já foi comprovada em jurisdições estrangeiras. (...) No Brasil, porém, quase não se tem notícia de ações privadas em razão de danos causados por cartéis. Perde-se, assim, um importante fator a desestimular a prática de conluio. E os prejudicados também deixam de ser ressarcidos pelos danos causados.
\end{abstract}

Os denominados public antitrust enforcement, mesmo que ainda, no geral, não sejam considerados como efetivamente abundantes, são os que apresentam uma maior recorrência no direito brasileiro quando da defesa do consumidor em relação a danos provenientes de ilícitos concorrenciais e, por isso mesmo, acabam configurando-se como a principal forma de tutela jurisdicional do consumidor pelas lesões sofridas no âmbito do direito da concorrência. Esse tipo de ação corresponde, justamente, a Ação Civil Pública.

Sobre o assunto, entende Demetrius Ferrreira Chacur (2012, p.89) que:

[...] o papel da ação civil pública como instrumento de tutela coletiva de combate às infrações à ordem econômica ganha destaque e se revela como elemento fundamental para garantir o equilíbrio no mercado.

Assim, mesmo que improvido em desfavor do consumidor, vale destacar decisão recente do Superior Tribunal de Justiça (julgada em 09 de maio de 2015) como exemplo da utilização da Ação Civil Pública no contexto neste artigo estudado. Ainda que a coletividade consumidora não tenha saído vitoriosa no Recurso Especial a seguir, o que se quer mostrar com sua colocação é o fato de ser a Ação Civil Pública é meio legítimo, concreto e o que vem sendo efetivamente utilizado para se buscar a tutela dos consumidores lesados por infrações concorrenciais. A seguir, ementa do Recurso Especial número 1390875 / RS, julgado pela Primeira Turma do Superior Tribunal de Justiça em 9 de junho de 2015:

ADMinistrativo E ECONÔMICO. AÇÃo CIVIL PÚBliCa. DANOS DIFUSOS AOS CONSUMIDORES. INFRAÇÕES À ORDEM ECONÔMICA. GLP. DISTRIBUIDORAS. FORMAÇÃO DE CARTEL. NÃO OCORRÊNCIA. APLICAÇÃO DA STATE ACTION DOCTRINE. ATUAÇÃO DAS DISTRIBUIDORAS IMUNES AO CONTROLE DO ÓRGÃO ANTITRUSTE.

${ }^{18}$ Conforme noticiado pela reportagem "Justiça manda anular maior multa da história do CADE." da Folha de São Paulo de 16 de setembro de 2015. 
Atuação do Cade e do Poder Judiciário na Questão da Responsabilidade Civil Configurada em Razão de Ilícitos Concorrenciais no Âmbito do Direito do Consumidor: Uma Análise das Decisões não Coincidentes

ATIVIDADE REGULADA E FISCALIZADA PELO ESTADO. ADVOCACIA DA CONCORRÊNCIA OU EDUCATIVA PARA PROMOÇÃO DE AMBIENTE LIVRE E COMPETITIVO. RECURSOS ESPECIAIS PROVIDOS. [...] (grifo nosso).

Como vem se afirmando ao longo do estudo, por mais que a Ação Civil Pública seja o principal instrumento utilizado no âmbito da problemática aqui abordada, o seu número ainda é muito pequeno se analisarmos o universo de situações em que elas seriam não só perfeitamente cabíveis como também necessárias. Essa baixa densidade se torna ainda mais evidente quando se observa as condenações do CADE por infrações à ordem econômica capazes de interferir negativamente no bem-estar do consumidor. Passemos, a seguir, a esta questão.

\section{Tutela jurisdicional $x$ atuação do CADE nos casos de infração à ordem econômica que afetam o consumidor: necessidade de harmonização}

É preciso compreender que as infrações concorrenciais que causam dano passível de reparação ao consumidor são, em geral, verdadeiros abusos cometidos na seara econômica e, por isso, tendo em vista a determinação constitucional ${ }^{19}$, devem ser reprimidos. Essa repressão pode se dar no âmbito cível (como o até agora estudado), administrativo e criminal.

De fato, um mesmo ato ilícito pode ensejar coibição nessas três áreas - e é até bastante provável que enseje. Para o presente artigo, porém, limitar-nos-emos a analisar a relação entre a tutela judicial e administrativa desses ilícitos.

Como dito, é um tanto quanto provável que uma infração concorrencial seja reprimível por mais de um ramo do direito. Conforme o Sistema Brasileiro de Defesa da Concorrência (SBDC) cabe ao Conselho Administrativo de Defesa Econômica (CADE), mais especificamente ao Tribunal Administrativo ${ }^{20}$ dessa autarquia, concretizar na seara

\footnotetext{
${ }^{19}$ É o que preleciona o art. 173 da Constituição Federal, a seguir transcrito: "ressalvados os casos previstos nesta Constituição, a exploração direta de atividade econômica pelo Estado só será permitida quando necessária aos imperativos da segurança nacional ou a relevante interesse coletivo, conforme definidos em lei. [...]§ $4^{\circ}$ A lei reprimirá o abuso do poder econômico que vise à dominação dos mercados, à eliminação da concorrência e ao aumento arbitrário dos lucros. (BRASIL. Constituição da República Federativa do Brasil,1988.)
}

${ }^{20}$ A Competência do Tribunal de encontra disposta no artigo $9^{\circ}$ de Lei 11.529/11. Destaquem-se os seguintes incisos: "Art. 9o Compete ao Plenário do Tribunal, dentre outras atribuições previstas nesta Lei: I - zelar pela observância desta Lei e seu regulamento e do regimento interno; II - decidir sobre a existência de infração à ordem econômica e aplicar as penalidades previstas em lei; III - decidir os processos administrativos para imposição de sanções administrativas por infrações à ordem econômica instaurados pela SuperintendênciaGeral; IV - ordenar providências que conduzam à cessação de infração à ordem econômica, dentro do prazo que determinar; V - aprovar os termos do compromisso de cessação de prática e do acordo em controle de concentrações, bem como determinar à Superintendência-Geral que fiscalize seu cumprimento; [...] X - apreciar 
administrativa a repressão ao abuso de poder econômico, cessando a conduta nociva à ordem econômica e, nos casos mais graves, sancionando e punindo aqueles que forem julgados infratores.

Ao CADE cabe apurar se de fato houve a concretização de uma ilegalidade concorrencial por um agente econômico. Sem dúvida, para que essa apuração seja feita, são, de certa forma, levados em conta a existência dos danos causados pela conduta - sejam eles aos consumidores, fornecedores, concorrentes ou ao próprio mercado em si considerado -, mas a mensuração deles não é feita, pois não é relevante para atuação do CADE.

Isso porque a essa autarquia cabe analisar se o ator econômico incorreu em conduta considerada ilegal, de modo que o foco é reprimir o agente economicamente ofensor, e não reparar os danos sofridos pelo ofendido. Caso este deseje ser indenizado, deve buscar a via judicial, de acordo com tudo que foi até agora explicitado. O viés de atuação do CADE repousa num caráter mais repressivo e sancionador, enquanto que o do Poder Judiciário apresenta uma faceta claramente reparadora.

Como aquilo que é atribuição do CADE realizar se mostra essencialmente diferente da atribuição conferida à esfera judicial, é natural que o exame do caso concreto e que os critérios adotados por ambas as searas para a tomada de decisão sejam diversos. Segundo Gaban e Domingues (2012, p. 132), na sua aferição da ilegalidade da ação do agente econômico, a referida autarquia federal perpassa, num primeiro momento, por três etapas, afirmando que se determinada conduta

[...] não restringe a livre concorrência (de forma efetiva ou em potencial), ou não acarreta a incidência do art. 20, ou do art. 36 de NLAB, não se pode falar na existência de conduta anticoncorrencial. A jurisprudência do CADE caminha majoritariamente nesse mesmo sentido, à medida que aplica o seguinte teste para aferir a ilegalidade de uma conduta na esfera antitruste: (i) Primeiro, é necessário mostrar que a conduta, por meio da qual a infração à concorrência se daria, de fato ocorreu e pode ser imputada à representada. (ii) Segundo, para que a prática empresarial possa configurar uma conduta anticompetitiva é necessário que a representada possua condições para realizar a alegada conduta infrativa, ou seja, que possua posição dominante que possa ser utilizada de modo a restringir a concorrência. (iii) Finalmente, uma vez tendo sido constatada a ação por meio da qual haveria restrições à concorrência por uma determinada empresa e detendo este poder de mercado, é necessário mostrar que tal conduta pode gerar efeitos deletérios à concorrência e que não esteja associada a ganhos de eficiência suficientes para contrabalançar os prejuízos de eventual redução da concorrência.

processos administrativos de atos de concentração econômica, na forma desta Lei, fixando, quando entender conveniente e oportuno, acordos em controle de atos de concentração”. (BRASIL. Lei n $\left.{ }^{\circ} 12.529,2011\right)$. 
Uma vez determinado que houve, de fato, conduta anticoncorrencial e que é cabível a multa sancionatória, o CADE passa para o segundo momento de exame, qual seja, a do cálculo dessa multa. Como já afirmado, a dimensão dos danos efetivamente causados não são apresentam relevância na esfera administrativa, e isso é perceptível nesta etapa, uma vez que eles não constituem a base de cálculo da multa a ser imposta.

É o capítulo III, intitulado "Das Penas", da Lei Antitruste Brasileira que determina as diretrizes a serem usadas na cominação da pena de multa, em especial o artigo $37^{21}$. Da sua análise, é possível perceber que os parâmetros levam mais em consideração características econômicas do agente ofensor (em especial o faturamento) do que a dos ofendidos. Diz-se "mais" e não "exclusivamente", tendo em vista que essa própria Lei, em seu artigo 45, coloca - dentre tantos outros balizadores focados no agente praticante do ilícito concorrencial - o grau de lesão, tanto a consumidores quanto a terceiro, como uma questão a ser levada em consideração. In verbis:

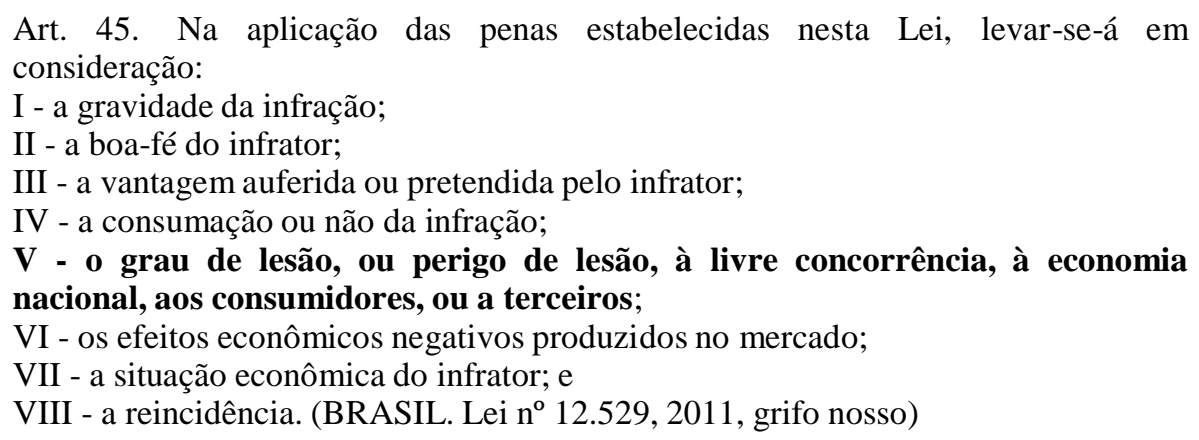

Essa influência da lesão por meio da determinação dessa agravante, entretanto, é um tanto quanto abstrata. Isso porque o estabelecimento do peso dessa lesão no cálculo da multa

\footnotetext{
${ }^{21}$ Art. 37. A prática de infração da ordem econômica sujeita os responsáveis às seguintes penas: I - no caso de empresa, multa de $0,1 \%$ (um décimo por cento) a $20 \%$ (vinte por cento) do valor do faturamento bruto da empresa, grupo ou conglomerado obtido, no último exercício anterior à instauração do processo administrativo, no ramo de atividade empresarial em que ocorreu a infração, a qual nunca será inferior à vantagem auferida, quando for possível sua estimação; II - no caso das demais pessoas físicas ou jurídicas de direito público ou privado, bem como quaisquer associações de entidades ou pessoas constituídas de fato ou de direito, ainda que temporariamente, com ou sem personalidade jurídica, que não exerçam atividade empresarial, não sendo possível utilizar-se o critério do valor do faturamento bruto, a multa será entre $R \$ 50.000,00$ (cinquenta mil reais) e $R \$$ 2.000.000.000,00 (dois bilhões de reais); III - no caso de administrador, direta ou indiretamente responsável pela infração cometida, quando comprovada a sua culpa ou dolo, multa de $1 \%$ (um por cento) a $20 \%$ (vinte por cento) daquela aplicada à empresa, no caso previsto no inciso I do caput deste artigo, ou às pessoas jurídicas ou entidades, nos casos previstos no inciso II do caput deste artigo. $\S 1^{\circ}$ Em caso de reincidência, as multas cominadas serão aplicadas em dobro. $\S 2^{\circ}$ No eálculo do valor da multa de que trata o inciso I do caput deste artigo, o Cade poderá considerar o faturamento total da empresa ou grupo de empresas, quando não dispuser do valor do faturamento no ramo de atividade empresarial em que ocorreu a infração, definido pelo Cade, ou quando este for apresentado de forma incompleta e/ou não demonstrado de forma inequívoca e idônea. (BRASIL. Lei $\left.\mathrm{n}^{\mathrm{o}} 12.529,2011\right)$.
} 
prescinde de uma criteriosa aferição do montante dos prejuízos efetivamente causados pela infração concorrencial. De fato, essa análise cabe ao judiciário, que a realiza quando provocado pelo prejudicado para alcançar a reparação dos danos.

Deve-se destacar que este órgão utiliza critérios bastante diferentes do CADE no procedimento de quantificação do dano, adotando para essa operação os parâmetros dos lucros cessantes e danos emergentes. No âmbito da reclamação de responsabilidade civil pelo consumidor por ilícitos concorrenciais, objeto do pressente estudo, é esse último critério que se apresenta como o de maior aplicabilidade, especialmente na modalidade do sobrepreço. Se na seara consumerista não há, em linhas gerais, o que se possa caracterizar como lucros efetivamente perdidos, o mesmo não pode se dizer dos efeitos do sobrepeço: esse aumento injustificado no preço do produto, em qualquer fase da cadeia produtiva e que seja repassado, impacta o montante a ser pago pelo consumidor final. Para jurisprudência brasileira, esse prejuízo é indenizável $^{22}$, e o cálculo dessa indenização leva em conta esse sobrepreço ${ }^{23}$.

De toda forma, ainda que um mesmo ilícito concorrencial cause danos e prejuízos tanto reprimíveis na esfera administrativa, quanto passíveis de serem reparados na esfera cível, a condenação ou absolvição por um órgão não vincula a decisão de condenar ou absolver do outro. Há casos, inclusive, em que um mesmo ato de infração não gerou decisões coincidentes entre os órgãos. Foi o que aconteceu no chamado "Cartel dos Cegonheiros" ${ }^{24}$, no qual houve absolvição pelo CADE por ausência de provas (Processo Administrativo $\mathrm{n}^{\circ}$ 080.12.005.669/202-31, julgado pelo Plenário do referido órgão em 21 de novembro de 2007)

\footnotetext{
22 Sobre o assunto, interessante citar o que traz André Marques Francisco (2014, p. 97) em sua dissertação: "antes de mais nada, é preciso esclarecer uma questão terminológica: fala-se aqui em 'vítima indireta' (o comprador indireto a quem o sobrepreço foi repassado), mas não de 'dano remoto'. Trata-se de distinção necessária, uma vez que a legislação civil estabeleceu que 'as perdas e danos só incluem os prejuízos efetivos e os lucros cessantes por efeito dela direto e imediato' (CC, art.403); a contrario sensu, entende-se que o 'dano remoto' não será enquadrável na categoria de dano indenizável. Entretanto, é preciso distinguir entre o 'dano remoto' e o chamado 'dano indireto' (ou 'dano por ricochete'); a diferença é que, muito embora o 'dano indireto' tenha na ação ou omissão sua causa direta e imediata, não se apresenta como a primeira manifestação do prejuízo ocasionado pelo ato ilícito. [...] Essa segunda diferenciação tem efeitos práticos relevantes, pois doutrina e jurisprudência admitem a responsabilidade civil decorrente do dano indireto - mas não do dano remoto - desde que devidamente comprovada sua extensão e sua correlação direta e imediata ao ato ilícito".

${ }^{23}$ Nas palavras de André Marques Francisco (2014, p. 84): “em regra, o sobrepreço pode ser calculado através de simples operação aritmética [...] O valor do sobrepreço seria então apresentado por um cálculo simples do preço praticado, menos o preço estimado não fosse a infração, multiplicado pelo volume negociado no período em que perdurou a prática.

${ }^{24}$ Nesse famoso caso, houve a apuração da existência de um suposto acordo entre a Associação Nacional dos Transportadores de Veículos (ANTV) e o Sindicato Nacional dos Transportadores Rodoviários Autônomos de Veículos e Pequenas e Micro Empresas de Transporte Rodoviário de Veículos (SINDICAM) que impedia que as empresas não cadastradas nessas referidas entidades circulassem pelas rodovias brasileiras transportando veículos novos, ocorrência que configuraria prática anticoncorrencial.
} 
Atuação do Cade e do Poder Judiciário na Questão da Responsabilidade Civil Configurada em Razão de Ilícitos Concorrenciais no Âmbito do Direito do Consumidor: Uma Análise das Decisões não Coincidentes

e condenação no Judiciário (Recurso Especial nº 677.585 - RS, julgado pela Primeira Turma do Superior Tribunal de Justiça em 06 de dezembro de 2005).

Isso se dá devido à independência que existe em Poder Executivo e Judiciário. São esferas apartadas que não se vinculam nem comunicam. Sobre isso, vale citar um trecho do acórdão do caso de cartel mencionado no parágrafo anterior:

\footnotetext{
[...] Deveras, a atuação paralela das entidades administrativas do setor (CADE e SDE), não inibe a intervenção do Judiciário in casu, por força do princípio da inafastabilidade, segundo o qual nenhuma ameaça ou lesão a direito deve escapar à apreciação do Poder Judiciário, posto inexistente em nosso sistema o contencioso administrativo e, a fortiori, desnecessária a exaustão da via extrajudicial para invocação da prestação jurisdicional.

[...] Inexiste violação ao princípio do ne bis in idem, tendo em vista a possibilidade de instauração concomitante de ação civil pública e de processo administrativo, in casu, perante a SDE - Secretaria de Desenvolvimento Econômico do Ministério da Justiça, para investigação e punição de um mesmo fato, porquanto as esferas de responsabilização civil, penal e administrativa são independentes. (STJ, RE n ${ }^{\circ} 677.585$ - RS, 2005). (grifos nossos).
}

Esse tipo de caso, no qual não há ilícito concorrencial segundo entendimento do CADE, mas há condenação por danos no judiciário, embora possível segundo nosso ordenamento e real ante a nossa jurisprudência, causa certa estranheza. Mais até do que a situação inversa (condenação no CADE e absolvição no Judiciário). Ora, um ilícito concorrencial de ocorrência confirmada pelo CADE pode não gerar dano; pode gerar um dano que, por algum motivo, não tenha sua reparação reclamada perante a máquina judiciária; ou pode esta negar que houve, de fato, a concretização do evento danoso. Lesões causadas por esse tipo de ilícito à esfera do consumidor podem se enquadrar nessa situação: muitas vezes a ilegalidade pode não afetar a esfera consumerista, o Judiciário pode não ser acionado ou então entender que o dano não se configurou.

Entretanto, chama atenção a possibilidade de ocorrência, diante do nosso ordenamento, de situações nas quais o CADE, órgão dotado de amplo conhecimento técnico e especializado em matéria concorrencial, decida que não houve ilícito, enquanto, em contrapartida, sobre uma mesma situação fática, o Judiciário entenda que restou configurada responsabilidade civil especialmente em relação ao dever de indenizar o consumidor, uma vez que se trata do tema em estudo.

Se causa perplexidade o fato de o CADE não considerar uma conduta como abusiva e o judiciário entender o contrário num caso em que não esteja em discussão a questão da responsabilidade civil, o que pensar de situações nas quais o mesmo ocorra, porém envolvendo questões indenizatórias? Como visto, a responsabilidade civil só se caracteriza 
quando há ato ilícito, dano, e nexo causal entres os dois primeiros. É um tanto quanto contraditório perceber que, devido à independência entre as esferas administrativa e judicial, é possível que a hipótese envolvendo situações indenizatórias aconteça.

É o CADE o órgão que possui corpo com verdadeira expertise em matéria concorrencial, diferentemente dos magistrados que integram o Poder Judiciário, que não a detém. Daí que se revela bastante estranho o fato de esses últimos poderem considerar como ato ilícito algo que o órgão especializado em direito da concorrência não considerou. é muito maior.

De fato, analisando em termos práticos, essa inconsonância parece não ser capaz de acarretar, imediatamente, consequências mais graves. Entretanto, caso seja frequente a sua ocorrência, é possível ela enseje um espécie de crise de credibilidade capaz de fragilizar a confiança que se deposita nessas instituições, uma vez que poderá parecer que elas não atuam em harmonia quando da defesa de interesses diferentes, mas que dizem respeito a toda coletividade.

Vale aqui lembrar a existência dos verdadeiros canais de comunicação entre o CADE e o Ministério Público Federal (MPF). Muito embora este último não integre o Poder Judiciário - nem aos outros dois poderes -, o fato de a lei prever atribuições dele (que é verdadeiro fiscalizador e guardião da aplicação da Carta Magna) junto ao CADE ${ }^{25}$ (como a emissão de pareces por um Procurador da República indicado pelo Procurador $\mathrm{Geral}^{26}$ ), bem como a participação do órgão administrativo como assistente nos casos em que esteja em discussão a aplicação da Lei $12.529 / 11^{27}$, denota uma intenção de fazer com que haja uma verdadeira colaboração entre os interesses diretos da coletividade e aqueles mais específicos do mercado concorrencial, a fim de restar concretizada uma harmonia entre ambas as linhas de pensamento.

\footnotetext{
${ }^{25}$ Essas atribuições junto ao CADE estão previstas na Lei $12.529 / 11$, nos seguintes artigos:

“Art. 9o Compete ao Plenário do Tribunal, dentre outras atribuições previstas nesta Lei: (...)§ 2o. As decisões do Tribunal não comportam revisão no âmbito do Poder Executivo, promovendo-se, de imediato, sua execução e comunicando-se, em seguida, ao Ministério Público, para as demais medidas legais cabíveis no âmbito de suas atribuições; Art. 20. O Procurador-Geral da República, ouvido o Conselho Superior, designará membro do Ministério Público Federal para, nesta qualidade, emitir parecer, nos processos administrativos para imposição de sanções administrativas por infrações à ordem econômica, de ofício ou a requerimento do Conselheiro- Relator; Art. 66. O inquérito administrativo, procedimento investigatório de natureza inquisitorial, será instaurado pela Superintendência-Geral para apuração de infrações à ordem econômica. (...) § 80. A Superintendência-Geral poderá solicitar o concurso da autoridade policial ou do Ministério Público nas investigações." (BRASIL. Lei n $12.529,2011)$

${ }^{26}$ Conforme o artigo 20 da Lei 12.529/11, já citado.

${ }^{27}$ Art. 118, da referida Lei: "Nos processos judiciais em que se discuta a aplicação desta Lei, o Cade deverá ser intimado para, querendo, intervir no feito na qualidade de assistente”. (BRASIL. Lei 11.529, 2011)
} 
Atuação do Cade e do Poder Judiciário na Questão da Responsabilidade Civil Configurada em Razão de Ilícitos Concorrenciais no Âmbito do Direito do Consumidor: Uma Análise das Decisões não Coincidentes

Como anteriormente afirmado, as ações de indenização em favor do consumidor por danos do direito da concorrência ainda são bastante incipientes no Brasil. Interessante seria se, na medida em que elas fossem crescendo em incidência, fossem tomados os devidos cuidados para que esse descompasso entre esfera cível e administrativa fosse evitado.

\section{CONCLUSÃO}

Ante todo o exposto, foi possível perceber que os efeitos do direito concorrencial não se restringem somente às questões de mercado, mas as extrapolam, atingindo, inclusive, a esfera do direito do consumidor. Tanto é assim que, como constatado, a Constituição Federal de 1988, bem como a legislação ordinária, tiveram a sensibilidade de fazer com que ambas as searas se cruzassem e se tocassem em diversas situações.

Umas delas é a questão da responsabilidade civil derivada de um ato ilícito concorrencial capaz de atingir a seara consumerista, ajuizada principalmente por meio de Ação Civil Pública. O estudo dos aspectos gerais desse tipo de ação confrontado com as decisões acerca de ilícitos concorrenciais pelo CADE, no âmbito administrativo, faz suscitar a possibilidade de decisões diferentes sobre um mesmo problema entre o executivo e o judiciário, especialmente nas situações em que o CADE entenda que não houve ato ilícito por parte do agente econômico enquanto o judiciário entenda pela ocorrência de responsabilidade civil. É estranho, paradoxal; mas, de acordo com o nosso ordenamento, passível de ocorrer.

Não é saudável nem interessante, porém, que isso aconteça. Imprescindível para evitar esses acontecimentos é o estreitamento do diálogo entre ambas as esferas. É bem verdade que o andamento de uma ação não é interrompido pelo ajuizamento da outra, de modo que um órgão não aguarda a decisão do outro para emitir a sua - até porque são independentes. Mas a comunicação entre, o estudo da jurisprudência e do posicionamento acerca do tipo de litígio em pauta de um pelo outro se mostram não só possíveis como essenciais.

As ações que visam à reparação do consumidor por danos decorrentes de ilícitos ocorridos na seara econômica são ainda bastante tímidas, existindo em número pequeno no Brasil. Entretanto, se percebe que, aos poucos, a sua quantidade vem crescendo, e seria bastante conveniente que ambas as entidades julgadoras estivessem cientes da possibilidade da ocorrência dessa dissonância, de modo que viessem a trabalhar em conjunto para que ela fosse evitada. De qualquer sorte, esse maior contato visando o aprimoramento de 
conhecimento entre judiciário e executivo seria um berço de vantagens para o ordenamento e para a coletividade em geral.

\section{REFERÊNCIAS BIBLIOGRÁFICAS}

BRASIL. Conselho Administrativo de Defesa Econômica. Processo Administrativo $\mathrm{n}^{\circ}$ 08012009888/2003-70. Relator: Conselheiro Fernando Magalhães Furlan. Julgado em 01 de setembro de 2010.

BRASIL. Constituição de 1934. Diário Oficial: 16 de julho de 1934.

BRASIL. Constituição da República Federativa do Brasil. Diário Oficial da União: 5 de outubro de 1988.

BRASIL. Lei nº 8.078 de 11 de setembro de 1990. Diário Oficial: 12 de setembro de 1990.

BRASIL. Lei $n^{\circ} 12.529$ de 30 de novembro de 2011. Diário Oficial da União: 01 de dezembro de 2011.

CADE. Perguntas Gerais sobre Defesa da Concorrência. Disponível em < http://www.cade.gov.br/Default.aspx?9d9061a878ad42c154e172c599bf> Acesso em 27.11.2015.

CARPENA, Heloisa. O consumidor no direito da concorrência. Rio de Janeiro: Renovar, 2005.

CARVALHO. Gilberto de Abreu Sodré. Concorrência e consumidor no âmbito da administração pública: uma relação a ser vista como de tensão no plano dos valores. Revista de Administração Pública, v. 38, n. 4, pp. 643-656, 2004.

CHACUR, Demetrius Ferreira. Ação Civil Pública para a proteção do mercado e da concorrência. Revista do Curso de Direito da Faculdade da Serra Gaúcha, ano 6 n. jul/dez 2012, pp. $83-93,2012$. 
Atuação do Cade e do Poder Judiciário na Questão da Responsabilidade Civil Configurada em Razão de Ilícitos Concorrenciais no Âmbito do Direito do Consumidor: Uma Análise das Decisões não Coincidentes

COMPARATO, Fábio Konder. Ensaios e pareceres de Direito Empresarial. Rio de Janeiro: Forense, 1978.

CRAVO, Daniela Copetti. Venda casada: é necessária a dúplice repressão? Revista de Defesa da Concorrência, n 1 , Maio 2013, pp. 52-70.

DIMOULINS, Dimitri; MARTINS, Leonardo. Teoria Geral dos Direitos Fundamentais. 2 ed. São Paulo: Editora Revistas dos Tribunais.

FIGUEIREDO, Leonardo Vizeu. Lições de Direito Econômico. 3 ed. Rio de Janeiro: Forense. 2010.

FRANCISCO, André Marques. Responsabilidade Civil por infração da ordem econômica. 2014, 156 f. Dissertação. Mestrado em Direito Comercial - Escola de Direito, Universidade de São Paulo, São Paulo

GABAN, Eduardo Molan. DOMINGUES, Juliana Oliveira. Direito Antitruste. 3 ed. São Paulo: Saraiva. 2012

GABAN, Eduardo Molan. SANTOS, Bruno Droghetti Magalhães. Reparação de danos no Direito Antitruste Brasileiro. Migalhas, 2011. Disponível em <http://www.migalhas.com.br/dePeso/16,MI140915,61044Reparacao+de+danos+no+Direito+ Antitruste+brasileiro> Acesso em 27. 11. 2015.

MARQUES, Cláudia Lima. Comentários ao Código de Defesa do Consumidor. $2^{\mathrm{a}}$ ed. rev. atual. e ampl., São Paulo: Editora Revista dos Tribunais, 2006.

MARTINS, Arthur Villamil. Indenização dos danos causados por cartéis: enforcement no combate às infrações da ordem econômica. Disponível em < http://www.nvaa.com.br/indenizacao-dos-danos-causados-por-carteis-enforcement-nocombate-as-infracoes-da-ordem-economica/> Acesso em 27. 11. 2015. 
MATION, Gisela Ferreira. As ações civis para cessação e reparação de danos causados por condutas anticoncorrenciais no Brasil. III Prêmio Seae de Monografias em Defesa da

Concorrência e Regulação Econômica, 2008. Disponível em < http://www.google.com.br/url?sa=t\&rct=j\&q=\&esrc=s\&source=web\&cd=1\&ved=0ahUKEwi Nq86T67PJAhUQO5AKHYttB1MQFgggMAA\&url=http\%3A\%2F\%2Fwww.esaf.fazenda.go v.br\%2Fpremios $\% 2$ Fpremios-1\%2Fpremios $\% 2$ Fviii-premio-seae-de-monografias-edicao2013\%2Fmonografias-2008\%2F2-lugar-tema-1estudantes\&usg=AFQjCNE2jYF6yffMZxcYK0-uXrk_mJWeNg> Acesso em 27.11.2015.

CARVALHO, Mario Cesar. Justiça manda anular maior multa da história do CADE. Folha de São Paulo, São Paulo, 16 set. 2015. Disponível em < http://www1.folha.uol.com.br/mercado/2015/09/1682221-justica-manda-anular-maior-multada-historia-do-cade.shtml> Acesso em 27.11.2015.

SALOMÃO FILHO, Calixto. Direito Concorrencial: as condutas. Malheiros: São Paulo, 2003.

Superior Tribunal de Justiça - STJ - Recurso Especial: 1390875 - RS 2013/0193352-3, Relator: Ministro NAPOLEÃO NUNES MAIA FILHO, Data de Julgamento: 09/06/2015, T1 - PRIMEIRA TURMA, Data de Publicação: DJe 19/06/2015

Superior Tribunal de Justiça - STJ, RECURSO ESPECIAL Nº 677.585 - RS (2004/01268898), Relator: Ministro LUIZ FUX, Data de Julgamento: 06/12/2005, T1 - PRIMEIRA TURMA. Data de Publicação: DJ 13/02/2006 p. 679. 